\title{
The Plankton as Indicators of Water Quality in Kusalla Reservoir: A Shallow Man Made Lake
}

\author{
Rabiu Musa Kutama, ${ }^{2}$ Mohammad Mustapha Abubakar and ${ }^{3}$ Mohammad Lawal \\ Balarabe \\ ${ }^{1}$ Department of Biology,Sa'adatu Rimi College of Education, Kumbotso \\ ${ }^{2}$ Department of Biological Sciences, Federal University Dutse, \\ ${ }^{3}$ Department of Biological Sciences,Ahmadu Bello University, Zaria.
}

\begin{abstract}
The composition, abundance and distribution of the plankton of Kusalla reservoir was studied between June 2006 and May 2007. With the aim of assessing the responses of the plankton to seasonal and spatial changes. Plankton samples were collected monthly from six sampling stations using standard methods. Eighteen species of phytoplankton belonging to four taxa were recorded. Twenty species of zooplankton from four taxa were observed. There was significant seasonal and spatial variation $(p=0.05)$ in the distribution of the phytoplankton and zooplankton. There was significant positive correlation $(r=0.7689)$ between the distribution and abundance of phytoplankton and zooplankton in Kusalla reservoir. Shannon-Weiner index of 5.17, 4.24 and 5.24 for stations 1,2 and 6 respectively indicate that these stations have a relatively high species diversity and therefore are not polluted. The distribution of the plankton shows that they are sensitive to changes in levels of nutrients and other interactions with one another and with other factors. As such the plankton can be good indicators of water quality.
\end{abstract}

Key Words: Composition, Distribution, Kusalla, Plankton

\section{Introduction}

The word plankton Originates from the Greek word meaning "wandering" According to Hosetti and Kumar (2002), Plankton is a collective term used to describe all those organisms whose power of movement are insufficient to prevent them from being moved by water currents. The Plankton can be classified in different ways, this include whether they are true or false plankton, their nutritional requirements (Phytoplankton and zooplankton), their size, their environments, and their life history. Kusuma et al., (1988) state that there is great diversity in the composition of plankton not only in different seasons and at different depths, but also at different hours, and probably even in different years in the same place and depth.

The plankton constitute the main producers in any given water body. According to Biddanda and Benner (1997) one of the main sources of carbohydrates in many aquatic systems is phytoplankton, where biomass is typically made up of from 15 to $35 \%$ carbohydrate. The production of dissolved compounds from phytoplankton is caused by direct exudation, predation and viral lysis. Direct exudation of dissolved organic carbon from phytoplankton is variable but most often varies within 5 to $20 \%$ of the primary production, so when phytoplankton are growing, carbohydrates are actively released in large amounts, and can contribute up to $70 \%$ of the Dissolved Organic Carbon (DOC) (Sondergaard et al., 2000).

Both phytoplankton and zooplankton are used in various ways as indicators of water quality. The quality of water, especially of eutrophic waters is essentially determined by the quantity of algae. Drinking water supply, recreational activities and fisheries can be impaired by high phytoplankton biomass. Therefore, water quality management has to monitor the phytoplankton content in order, for instance to come up with preventive measures such as aeration to prevent fish kills during the decay of the planktonic biomass (Imhof and Alberrecht, 1975). According to Khatri (1987) based on the distribution pattern of the plankton the quality of the environment can be assessed. Abubakar (1998) Observed that the seasonal and spatial distribution of phytoplankton in Salanta River can be used as an index to describe the level of pollution in the river. Zooplankton is mainly applied as species-indicators of saprobity or atrophic state of the system. For a long time, the use of zooplankton community characteristics as a tool in bioindication has been considered of rather low information value. However, zooplankton indices based on e.g. taxonomic composition, size distribution, trophic levels, spatial patterns, and functional characteristics and quantitative data may be of high informative potential and should not be overlooked in monitoring studies (Andronikova, 1996).

Lovik and Kjellberg (2003) observed that trophic changes in lake environments could be highlighted through the study of the structure and composition of the planktonic communities, and the observation of the principal physical and chemical parameters of the waters. Such changes allow us to draw useful pictures about the state of water quality in the lake and on its trophic state. The objective of the present study is to assess the 
composition of the plankton, determine their responses to seasonal and spatial variations and to assess their diversity indices in the reservoir.

\section{Materials And Methods}

\section{Study Area}

Kusalla reservoir is located at Kusalla village on latitude $10^{\circ} 02^{\circ} \mathrm{N}-11^{\circ} 00^{\circ} \mathrm{N}$ and longitude $11^{\circ} 42^{`} \mathrm{E}-$ $12^{0} 42^{\circ} \mathrm{E}$. It is in the Sudan savanna zone of Nigeria, with two distinct seasons (wet and dry). The rainy season period lasts from May to October and dry season from November to April. Kusalla reservoir is approximately 90km southwest of Kano city. The dam was impounded in 1969 and commissioned in 1970. It has two major tributaries, river Kunkun and river Makugara. It covers about 200heactres with about 17.3 million cubic meters water capacity. About 1 million people depend on the dam for their water supply, irrigation, livestock farming and fishing.

\section{Sampling Stations}

Six sampling stations were chosen for the study. Station 1 at the dammed site where human activities like washing, bathing, are taking place. Station 2 at the tower point where there are less human activities. Station 3 at the deepest part of the reservoir and station 4 near the middle of the Dam. $5^{\text {th }}$ station at the entrance point of river Makugara and $6^{\text {th }}$ station at the entrance point of river Kunkun both of which are rivers supplying water to Kusalla reservoir (Figure 1.)

\section{Collection of Plankton}

Sample of plankton were collected using plankton net of mesh size 70um (microns). The net was tied to a metal rod, and immersed into the water, towed for a fixed distance, and hauled out of the water. The water (containing plankton) that was collected in the plastic bottle at the end of the net was emptied into sample bottles and preserved with $4 \%$ formalin, for zooplankton and Lugol's solution, for phytoplankton (Vollenweder, 1974, Wetzel and Likens, 1979). The volume of water that passed through the net was then estimated by using the following formula:

$\mathrm{V}=\pi \mathrm{r}^{2} \mathrm{~d}$

Where $\mathrm{V}=$ volume of water filtered by the net, = radius of the mouth of the net and $\mathrm{d}=$ length of the haul (Downing and Rigler, 1982).

\section{Plankton Enumeration}

On coming to the laboratory, the phytoplankton samples were condensed by centrifuging $100 \mathrm{ml}$ of the sample to $10 \mathrm{mI}$. The concentrated sample was taken for enumeration with Sedgwick-Rafter counting chamber. Identification was done to species level, using keys in Palmer (1980) for phytoplankton and Jeje and Fernando (1986) for zooplankton. Data collected were subjected to analysis of variance (ANOVA), Pearson's product moment correlation coefficient and Duncan's multiple range tests.

\section{Results}

Results of the seasonal and spatial distribution of phytoplankton in Kusalla reservoir is presented in table 1 . The phytoplankton was generally more numerous during the rainy season (June-October).

Table 1: monthly values of phytoplankton per station (ind/l)

\begin{tabular}{lllllll}
\hline \multicolumn{1}{c}{ Station } & 1 & 2 & 3 & 4 & 5 & 6 \\
\hline Month & 230 & 223 & 154 & 124 & 72 & 255 \\
June 2006 & 241 & 223 & 167 & 141 & 84 & 271 \\
July 2006 & 262 & 234 & 180 & 154 & 95 & 276 \\
August 2006 & 222 & 201 & 142 & 125 & 87 & 224 \\
September 2006 & 163 & 157 & 121 & 100 & 71 & 187 \\
October 2006 & 123 & 139 & 110 & 80 & 53 & 169 \\
November 2006 & 102 & 112 & 80 & 64 & 43 & 127 \\
December 2006 & 80 & 93 & 64 & 51 & 34 & 106 \\
January 2007 & 72 & 71 & 56 & 44 & 30 & 97 \\
February 2007 & 61 & 72 & 76 & 49 & 35 & 89 \\
March 2007 & 95 & 95 & 91 & 72 & 43 & 114 \\
April 2007 & 168 & 146 & 105 & 87 & 59 & 152 \\
May 2007 & & & & & & \\
\hline
\end{tabular}

The phytoplankton biomass was higher in stations 6 and 1 . And it was lower in stations 4 and 5 .

Stations 1,2 and 6 had the highest biomass of phytoplankton in the reservoir. The phytoplankton is made up of 18 species from 4 taxa. The chlorophyta dominates the taxa with $36.25 \%$, this is followed by the Cyanophyta (30.06\%), Bacillariophyta (27.66\%) and Dinophyta (7.03\%). The phytoplankton showed significant variation $(\mathrm{p}=0.01)$ in distribution both seasonally and spatially. 
The zooplankton of Kusalla reservoir consists of four classes, with twenty species of zooplankton. The zooplankton is dominated by the Cladocera both in terms of number of individuals and number of species. The Cladocera makes up $37.95 \%$ of the zooplankton with 8 species. This is followed by the Copepoda with 4 species making up $26.60 \%$, the Rotifera with 5 species makes up $19.69 \%$ and the Protozoa makes up $15.76 \%$ with 3 species. There was significant seasonal and spatial variation $(\mathrm{p}=0.05)$ in the distribution of the zooplankton. There was significant positive correlation $(\mathrm{r}=0.7689)$ between the distribution and abundance of phytoplankton and zooplankton in Kusalla reservoir.

Shannon-Weiner index of 5.17, 4.24 and 5.24 for stations 1,2 and 6 respectively indicate that these stations have a relatively high species diversity and therefore are not polluted. But stations 3 and 4 with indexes of 2.11 and 1.81 respectively have relatively lower species diversity suggesting possible pollution.

Table 2: mean distribution of zooplankton in Kusalla reservoir and the diversity indices of the stations

\begin{tabular}{|c|c|c|c|c|c|c|c|}
\hline Station & 1 & 2 & 3 & 4 & 5 & 6 & Total \\
\hline \multicolumn{8}{|l|}{ Protozoa } \\
\hline Euglena Spp & 17 & 12 & 7 & 2 & 8 & 15 & 61 \\
\hline Paramecium Spp & 13 & 9 & 6 & 3 & 11 & 14 & 56 \\
\hline Chlamydomonas Spp & 19 & 17 & 11 & 5 & 18 & 21 & 91 \\
\hline \multicolumn{8}{|l|}{ Cladocera } \\
\hline Daphnia Spp & 25 & 16 & 9 & 5 & 12 & 18 & 85 \\
\hline Simocephalus Spp & 11 & 3 & 5 & 4 & 13 & 14 & 50 \\
\hline Ceriodaphnia Spp & 22 & 19 & 17 & 2 & 11 & 15 & 86 \\
\hline Bosmina Spp & 18 & 17 & 9 & 7 & 15 & 15 & 81 \\
\hline Macrothria Spp & 12 & 19 & 10 & 4 & 24 & 18 & 87 \\
\hline Polyphemis Spp & 10 & 7 & 2 & 2 & 9 & 12 & 42 \\
\hline Eurycercus Spp & 7 & 5 & 0 & 0 & 3 & 5 & 21 \\
\hline \multicolumn{8}{|l|}{ Copepoda } \\
\hline Diaptomus Spp & 12 & 19 & 5 & 3 & 12 & 10 & 61 \\
\hline Cyclops Spp & 25 & 17 & 12 & 5 & 19 & 21 & 99 \\
\hline Namplii Spp & 24 & 19 & 15 & 7 & 18 & 22 & 105 \\
\hline Eubranchipus Spp & 11 & 10 & 8 & 3 & 12 & 8 & 52 \\
\hline \multicolumn{8}{|l|}{ Rotifera } \\
\hline Kellicottia Spp & 17 & 12 & 11 & 8 & 21 & 26 & 95 \\
\hline Keratella Spp & 21 & 11 & 9 & 4 & 18 & 16 & 79 \\
\hline Brachionus Spp & 15 & 12 & 3 & 0 & 5 & 7 & 42 \\
\hline Chromogaster Spp & 19 & 2 & 5 & 0 & 7 & 9 & 44 \\
\hline Rotaria Spp & 18 & 16 & 7 & 4 & 9 & 5 & 59 \\
\hline Mean No of Ind. (N) & & 276 & 88 & 43 & 212 & 315 & 784 \\
\hline No. of Species (S) 19 & & 19 & 18 & 15 & 19 & 19 & \\
\hline Shannon-Weiner Index (D)5.17 & & 4.24 & 2.11 & 1.81 & 3.98 & 5.24 & \\
\hline Euenness Index $(\mathrm{E}) \quad 0.975$ & & 0.866 & 0.621 & 0.311 & 0.921 & 0.986 & \\
\hline
\end{tabular}

\section{Discussion}

The composition of plankton in Kusalla reservoir agrees with the findings of several workers in Nigerian waters. Abdullahi and Indabawa (2005) show that the phytoplankton of River Hadejia consists of Chlorophyta (40\%), Cyanophyta (30\%) Bacillariophyta (24\%), Euglenophyta (35), Dinophyta 1\%) and Chrysophyta (0.6\%). Lamai and Kolo (2003) studied the zooplankton of Dan-Zaria dam and observed about 40 taxa dominated by the Rotifers $(35.38 \%)$, Protozoa $(27.03 \%)$ Cladocerans $(25.54 \%)$ and the Copepoda $(12.05 \%)$.

The quality of any given water body is influenced by physical and chemical factors. These physicochemical parameters interact with one another and with more than one parameter at a time to greatly influence the water quality characteristic. Many workers have carried out studies on the effect of different physicochemical parameters on aquatic organisms. Lovik and Kjellberg (2003) observed that trophic changes in lake environments could be highlighted through the study of the structure and composition of the planktonic communities, and the observation of the principal physical and chemical parameters of the waters. Such changes allow us to draw useful pictures about the state of water quality in the lake and on its trophic state. Studies by Boyd et al., (2000) have shown that the mineral element iron can cause increased blooms of many kinds of phytoplankton. The composition and abundance of phytoplankton and zooplankton in a water body clearly indicates the health status of the water body. The plankton show different responses to different environmental conditions. ). According to Pannard et al., (2007) depending on the season the phytoplankton responses differed with respect to nutrient and light conditions, and to the intensity of stratification and mixing. The high abundance of phytoplankton in stations 1,2 and since, coincided with entry points of nutrients into the reservoir. According to several workers, nutritive substances chiefly determine the abundance of plankton of any place. According to Walker et al., (2001) the input of nutrients, is the most significant factor affecting phytoplankton biomass and distribution in the Nyara estuary. They showed that when not receiving pulses of nutrients through freshwater inflow the estuary is a predominantly low nutrient, low phytoplankton biomass, 
stratified system, dominated by microbial food web. However, this state is altered rapidly by flood events. Barlow et al., (2006) are of the opinion that because of upwelling, phytoplankton biomass and composition, in Namibian waters are highly variable.

The conditions that lead to maxima and minima, as well as to minor fluctuations or abundance of any particular plankton are complex, in their physical, chemical and biological aspects. According to Hosetti and Kumar (2002), Plankton communities are always in the process of change. At any spot changes may occur in the kind of phytoplankton and zooplankton that are present and in the relative and absolute number of the several species. Investigation in Namibian waters revealed that during spring, diatoms dominated Phytoplankton communities while the flagellates were dominant in summer, and Dinoflagellates and prokaryotes were present throughout.

Zooplankton densities in pelagic zones of water bodies are low, but considerably higher in shallow littoral zones. Isumbisho et al., (2006) observed that each year, the total crustacean zooplankton of Lake Kivu increased to a distinct seasonal maximum following a rise of phytoplankton production associated with a deep epilimnetic mixing in the dry season. This dependence on phytoplankton suggests that zooplankton in Lake Kivu is mainly bottom-up controlled. This opinion is in comformity with the findings of the present study which shows positive correlation between the distribution of phytoplankton and zooplankton.

\section{Conclusion}

The phytoplankton are responsible for a percentage of all primary production in any given water body. The zooplankton, fish and other organisms in turn graze upon the phytoplanktons. Therefore, the availability of phytoplankton directly affects the abundance and distribution of zooplankton. The seasonal and spatial distribution of the plankton in this study shows the they are sensitive to changes in levels of nutrients and other interactions with one another and with other factors. As such the plankton can be good indicators of water quality.

\section{References}

[1]. Abdullahi, B. A. and Indabawa, I. I. (2005). Ecology of Freshwater

[2]. Phytoplankton of River Hadejia, Jigawa State, Nigeria. Biological and Environmental Sciences Journal for the Tropics. 1(2): 14114.

[3]. Abubakar, M. M. (1998). Effects of pollution on phytoplankton distribution in Salanta and Challawa rivers, Kano Nigeria. M.Sc. Thesis, Bayero University, Kano (unpublished).

[4]. Andronikova, I. N. (1996). Zooplankton characteristics in monitoring Lake Ladoga. Hydrobiologia 322: 173-179.

[5]. Barlow, R., Louw, D., Balarin, M. and Alheit, J. (2006). Pigment signatures of phytoplankton composition in the northern Benguela ecosystem during spring. African Journal of Marine Sciences, 28(3\&4): 479-491.

[6]. Biddanda, B. and Benner, R. (1997). Carbon, nitrogen and carbohydrate fluxes during the production of particulate and dissolved organic matter by marine phytoplankton. Limnology and Oceanography, 42: 506-518.

[7]. Boyd, P.W., Wong, R. and Lee, H. (2000). A meso scale phytoplankton bloom in the polar southern ocean stimulated by iron fertilization. Nature 407: $695-702$.

[8]. Downing, J. A. and Rigler, F. H. (1984). A Manual of Methods for the

[9]. assessment of secondary productivity in fresh waters (2 $2^{\text {nd }}$ ed.) Blackwell Scientific Publications, Oxford, UK

[10]. Hosetti, B. B. and Kumar, A. (2002). A textbook of applied aquatic Biology, Daya Publishing House, Delhi. $217-257$.

[11]. Imhoff, K. R. and Alberrecht, D. (1975). Oxygen dynamics in the impounded lower Ruh River Programme. Water Technology 7(314). 505-518.

[12]. Isumbisho, M. H., Sarmento, B., Kaningini, J., Micha, S. and Desay, J. (2006). Zooplankton of Lake Kivu, East Africa half a century after the Tanganyika Sardine introduction. Journal of Plankton Research 28(II) : $971-989$.

[13]. Jeje, C.Y. and Fernando, C.K. (1986). A practical guide to the

[14]. identification of Nigeria Zooplankton: Kainji Lake Institute.

[15]. Khatri, T. C. (1987). Seasonal distribution of phytoplankton in Iduki reservoir of Kerala, India. Environmental and Ecology 5: 71 73.

[16]. Kusuma, M. S., Neelakanton, B. and Konnur, R. G. (1988). Plankton distribution in the Kali Estuary, Karwar Central West Coast of India, Environmental and Ecology. $115-119$.

[17]. Lamai, S. L. and Kolo, R. J. (2003). Biodiversity and abundance of fish and plankton of Dan-Zaria Dam, Niger State, Nigeria. Journal of Aquatic Sciences 18 (2) 141-148.

[18]. Lovik, J. E. and Kjellberg, G. (2003). Long term changes of the crustacean zooplankton Community in Lake Ngosa the largest lake in Norway. Limnology 62: $143-150$.

[19]. Palmer, C. M. (1980) Algae relation to water quality in Pensylvania. Proc. Pa. Acad Sci.,: 41 pp 73-85.

[20]. Pannard, A. M., Bormans, R. and Lagadeue, Y. (2007). Short-term variability in physical forcing in temperate reservoir effects on phytoplankton dynamics and sedimentry fluxes. Freshwater Biology 52 (1) 12.

[21]. Sondergaard, M., Williams, P.J., Cauwet, G., Riemann, B., Robinson, C., Terzic, S., Woodward, E.M.S. and Worm, J. (2000). Net accumulation and flux of dissolved organic nitrogen in marine plankton communities. Limnology and Oceanography 45: 10971111.

[22]. Vollenweider, R. A. (1974). A manual on methods for measuring primary production in aquatic environments. IBP Handbook no. 12. Blackwell Scientific Publications, London.

[23]. Walker, D., Perissinotto, R. and Bally, R. P. A. (2001). Phytoplankton / protozoan dynamics in the Nyara estuary; a small temporary open system in eastern cape (South Africa). African Journal of Aquatic Science 26(1) : $31-38$.

[24]. Wetzel, R.G. and Likens, G.E. (1979). Limnological Analysis. W.B. Saunders Philadelphia. pp357. 